\title{
The Effect of Different Feed Formulation Based on Local Feed Resource on Performance and Stress Parameter in Breeder Goat
}

\author{
Shahudin $\mathrm{MS}^{2}$, Ghani AAA ${ }^{2}$, Zamri-Saad $\mathrm{M}^{1}$, Zuki AB ${ }^{1}$, Abdullah $\mathrm{FFJ}^{1}$, Wahid $\mathrm{H}^{1}$, Roslee MSA ${ }^{2}$, \\ Hamzah $\mathrm{H}^{3}$, Hassim $\mathrm{HA}^{1,2,3}$ \\ ${ }^{1}$ Research Centre for Ruminant Diseases \\ ${ }^{2}$ Department of Veterinary Preclinical Sciences \\ ${ }^{3}$ Department of Pathology and Microbiology, Faculty of Veterinary Medicine \\ Universiti Putra Malaysia, 43400 UPM Serdang, Selangor, Malaysia \\ haslizaabu@upm.edu.my
}

\begin{abstract}
Balanced nutrition is essential for health and performance of livestock. It is best when feed is formulated according to production stages of goat. However, as the goat grows, it may undergo transition of different feed formulation to meet its daily requirement. The transition may affect the performance of animals as well as it is a stressful condition. In this study, body weight gain and feed intake were used as indicators on performance, whereas hematological stress leucograms were used as indicator of stress parameter during implementation of different feed formulation among does. Eighteen adult does with similar body condition score and body weight approximately $20 \mathrm{~kg}$ were selected and divided into three groups equally $(\mathrm{n}=6)$ and fed with different feed formulations, which were formulated using local feed source in the farm for a period of four weeks. Body weight was measured before implementation, on week 2 and week 4, blood sampling was conducted before implementation and during week 4 for comparison and feed intake was measured every day. All data were statistically analyzed using SPSS. Does fed with Diet 3 showed highest body weight gain and feed intake, followed by Diet 2 and Diet 1 . There was significant difference $(\mathrm{P}<0.05)$ on body weight gain for all groups. Stress parameter on leucocyte counts for Diet 1 showed the highest number as compared to the other groups but no significant difference $(\mathrm{P}>0.05)$ as compared to normal value. Neutrophils:lymphocytes ratio for all groups were within normal range and no significant difference $(\mathrm{P}>0.05)$. The implementation of feed formulation according to production stages is recommended as it increases performance and prevents from nutritional stress.
\end{abstract}

Key Words: Body Weight Gain, Feed Formulation, Feed Intake, Neutrophils:Lymphocytes Ratio, Stress Leucogram

\section{INTRODUCTION}

Goat is an important contributor to milk, meat and hide production in many developing countries. Indeed, goat industry plays a major role in livestock production in Asia in which it has been dominated by smallholders. In 2010, Ministry of Agriculture, Malaysia had reported that the population of goats is about $34 \%$ of the total ruminant sector among overall livestock industry in the country. Thus, in order to ensure sustainability of goat industry in the future, a long-term structured strategy is needed to be considered which include herd health, breeding and nutritional management (Mustafa et al. 2010).

A balanced nutritional value is the basis of successful production as well as promoting a good health to the goat (Sultana et al. 2012). In normal practice, feed which includes forage and concentrate are formulated in order to meet goats daily requirement (Filley et al. 2006). However, one of the major constraints in developing ruminant industry in Malaysia is the difficulty to provide sufficient feed in terms of quantity and quality forage throughout the year (Abubakr et al. 2015). This problem occurs due to many factors such 
as poor soil fertility, inconsistent suitable weather for grass growth and lack of natural grassland (Devendra 2013). In order to overcome this problem, different feed formulationscombined with local feed resources had been introduced according to the production stages of the goat.

As one of the largest producers of soy drink in Southeast Asia, some livestock farmers in Malaysia have already used soy waste as their alternative source of feed to their animals (Rahman et al. 2014). This is because besides there is an abundant source of soy waste that could be used as an alternative livestock feed, it is also said to has high nutritional value in term of protein and energy source (Harjanti 2012). According to Ramsey (2012), soy waste could be used in goat's diet up to $20 \%$ to replace commercial pellets and it did not compromises the post weaning growth and performance of goats. Other than using industrial by-product such as soy bean as an alternative source of feed, exploitation of local plant (e.g. Mallotus sp. and Macaranga sp.) can be successfully used as an alternative source of feed for small ruminant diets without compromising animal performance. According to Ghani et al. (2015), these local plants are suitable to be used as feed as its contents are high in protein and energy which can help the goats to get adequate nutrient from their diets.

Transition of different feed formulation has been reported to cause stressful condition to the goats. Stress level is crucial in the livestock industry because it may affect directly on growth, reproduction, meat quality, animal welfare and disease susceptibility. Thus, it has the potential for making a substantial economic impact. Lacking in nutritional availability is regarded as one of the stressors among goat husbandry practices, apart from environmental and handling. However, specific manifestation of stress can be measured on the blood results such as concentration of white blood cells particularly on stress leucograms, total red blood cells, hemoglobin levels (Alam et al. 2011) as well as blood cortisol level (Fazio et al. 2006). There is still little information on the effects of local feed resources such as soy waste, Mallotus sp. (Balik Angin) and Macaranga sp. (lebar daun) on the performance of goats particularly on the growth and feed intake. Therefore, this study investigates the response of goats to different proportion of local feed resources and to asses stress level of the goats due to transition of different feed formulation.

\section{MATERIAL AND METHODS}

\section{Experimental design}

In this study, Boer cross breeders aged one-year-old and approximately weighing about $20 \mathrm{~kg}$ were selected and divided into three groups which consisted six does for each group. Three different diets were formulated and given to each group of does. All diets were consist of local feed resources such as Pennisetum purpureum (Napier grass), Mallotus sp. (Balik Angin), Macaranga sp. (Lebar Daun), soy waste and concentrate with different proportions (Table 1). Nutrient composition in each different group was also stated in Table 2.

At the beginning of the experiment, a proper physical examination was conducted for each doe. Then, does were put into individual pen and blood sampling and body weight were measured and recorded for baseline data. The does were fed according to the assigned feed formulation for 4 weeks. Body weight was measured before implementation, at week 2 and week 4, whereas blood sampling was conducted before implementation and at week 4 and for feed intake, the measurement was done daily. 
Table 1. The feed ingredients in diet 1, diet 2 and diet 3

\begin{tabular}{lccc}
\hline \hline Local feed resources & $\begin{array}{c}\text { Diet } 1 \\
(\mathrm{~g})\end{array}$ & $\begin{array}{c}\text { Diet } 2 \\
(\mathrm{~g})\end{array}$ & $\begin{array}{c}\text { Diet } 3 \\
(\mathrm{~g})\end{array}$ \\
\hline Pennisetumpurpureum & 1600 & 1400 & 1370 \\
Mallotus sp. & 380 & 460 & 540 \\
Macaranga sp. & 380 & 460 & 540 \\
Soy waste & 810 & 930 & 940 \\
Concentrate & 330 & 250 & 110 \\
\hline Total & 3500 & 3500 & 3500 \\
\hline
\end{tabular}

Table 2. Nutrient composition in different feed formulations

\begin{tabular}{lccc}
\hline \hline $\begin{array}{l}\text { Nutrient composition } \\
(\% \text { DM })\end{array}$ & Diet 1 & Diet 2 & Diet 3 \\
\hline Dry matter & 65.37 & 68.73 & 71.36 \\
Ash & 10.31 & 12.98 & 11.23 \\
Crude fiber & 20.44 & 20.44 & 20.35 \\
Crude protein & 13.56 & 14.81 & 20.01 \\
Crude fat & 2.10 & 2.27 & 2.36 \\
\hline
\end{tabular}

DM: dry matter

\section{Measurement of the body weight gain and feed intake}

Body weight was measured firstly at the start of experiment and was done again at Week 2 and Week 4. The readings were recorded and tabulated for comparison. Then, from the data, average daily gain was calculated and recorded to further evaluate effectiveness of feed formulation. The body weight gain and average daily gain was calculated by using this formula:

Body weight gain $(\mathrm{kg})=$ Final body weight $(\mathrm{kg})-$ Initial body weight $(\mathrm{kg})$

Average daily gain $\left[\frac{\mathrm{g}}{\text { day }}\right]=\frac{\text { Body weight gain }(\mathrm{g})}{\text { Experimental period (day) }}$

\section{Feed intake calculation}

The amount of feed offered was measured (Diet 1), which was about 3.5 $\mathrm{kg} /$ day/animal. Then, based on availability of feed supply in the farm, the feed was formulated according to maintenance requirements of breeder goat. Feed were given to the animals twice daily and the feed left over was measured the next day to calculate feed intake.

\section{Blood sampling}

Blood samplings were carried out at the beginning of experiment and at week 4 . Blood samples were collected by venipuncture of the jugular vein. Prior to the vein 
puncture, the area for blood collection was swabbed with $70 \%$ alcohol. Then, approximately $10 \mathrm{ml}$ of blood was drawn out using a 21-gauge needle (Venoject $囚$ ) into EDTA tube for hematological study. All blood samples were analyzed at clinical pathology laboratory using MS4-Hematology Cell Analyzer to perform complete blood count. The packed cell volume (PCV) was determined using micro-hematocrit centrifuge. For stress leucograms, blood morphology was analyzed in which routine thin blood smears were made from the blood in EDTA tube before the white blood cell (WBC) count was carried out. The smears were air dried and stained with Diff-Quick stain for 3 minutes. Excess stain was removed by allowing slow running tap water onto the smears. The slides were then being immersed in phosphate buffer solution of $\mathrm{pH} 7.2$ for another 30 minutes. Differential counts of WBC were carried out under a light microscope, which included percentages of neutrophils, lymphocytes, monocytes, basophils, and eosinophils under oil immersion with 100× magnification. The battlement method of counting was chosen to count the represent sample of the blood cells from the smears.

All data were analyzed using Statistical Package for the Social Science (SPSS) version 22.0 where $\mathrm{P}<0.05$ indicates significant difference and $\mathrm{P}>0.05$ indicates no significant difference for the results.

\section{RESULTS AND DISCUSSION}

\section{Results}

\section{Body weight gain}

Body weight gain after fed with different feed formulation (Diet 1, 2 and 3) for 4 weeks was presented in Fig. 1 with the highest on Diet 3, followed by Diet 2 and Diet 1.

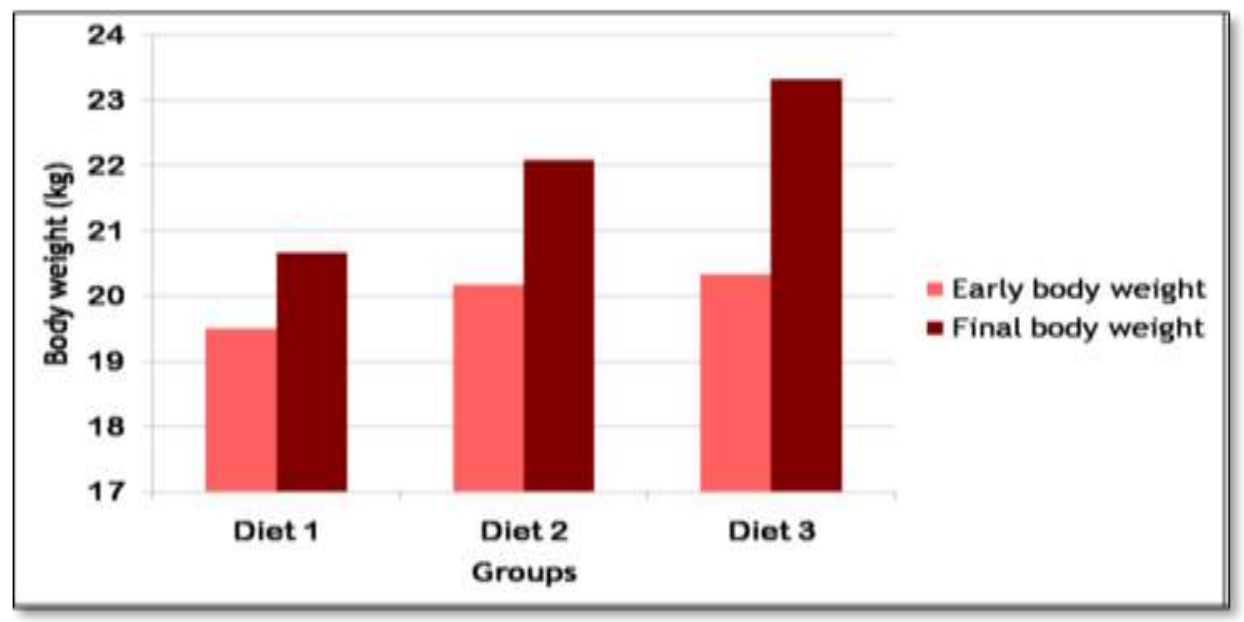

Figure 1. The comparison of body weight gain for Diet 1, Diet 2 and Diet 3

The body weight gain showed the highest on Diet 3 which was $3.00 \mathrm{~kg}$, followed by Diet 2 which was $1.92 \mathrm{~kg}$ and Diet 1 which was $1.17 \mathrm{~kg}$. Thus, from this data average daily gain was further evaluated (Figure 2). Diet 3 showed the highest average daily gain which was $106.07 \mathrm{~g} /$ day, followed by Diet 2 which was $68.97 \mathrm{~g} /$ day and Diet 1 which was $41.79 \mathrm{~g} /$ day. 


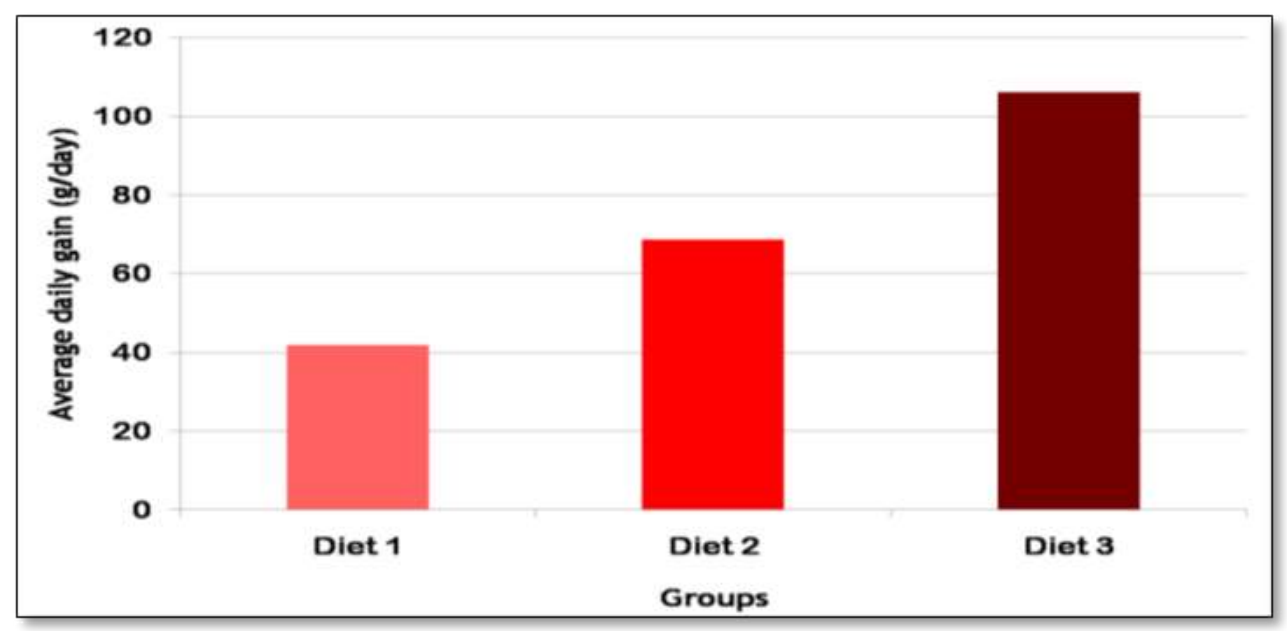

Figure 2. The average daily gain for Diet 1, Diet 2 and Diet 3

\section{Feed intake}

After four week of experimental period, feed intake value for daily basis of Diet 1, Diet 2 and Diet 3 were $2.6 \mathrm{~kg}, 2.7 \mathrm{~kg}$ and $3.3 \mathrm{~kg}$ respectively. For feed intake value for daily dry matter for Diet 1, Diet 2 and Diet 3 were $2.5 \mathrm{~kg}, 2.1 \mathrm{~kg}$ and $2.1 \mathrm{~kg}$ respectively.

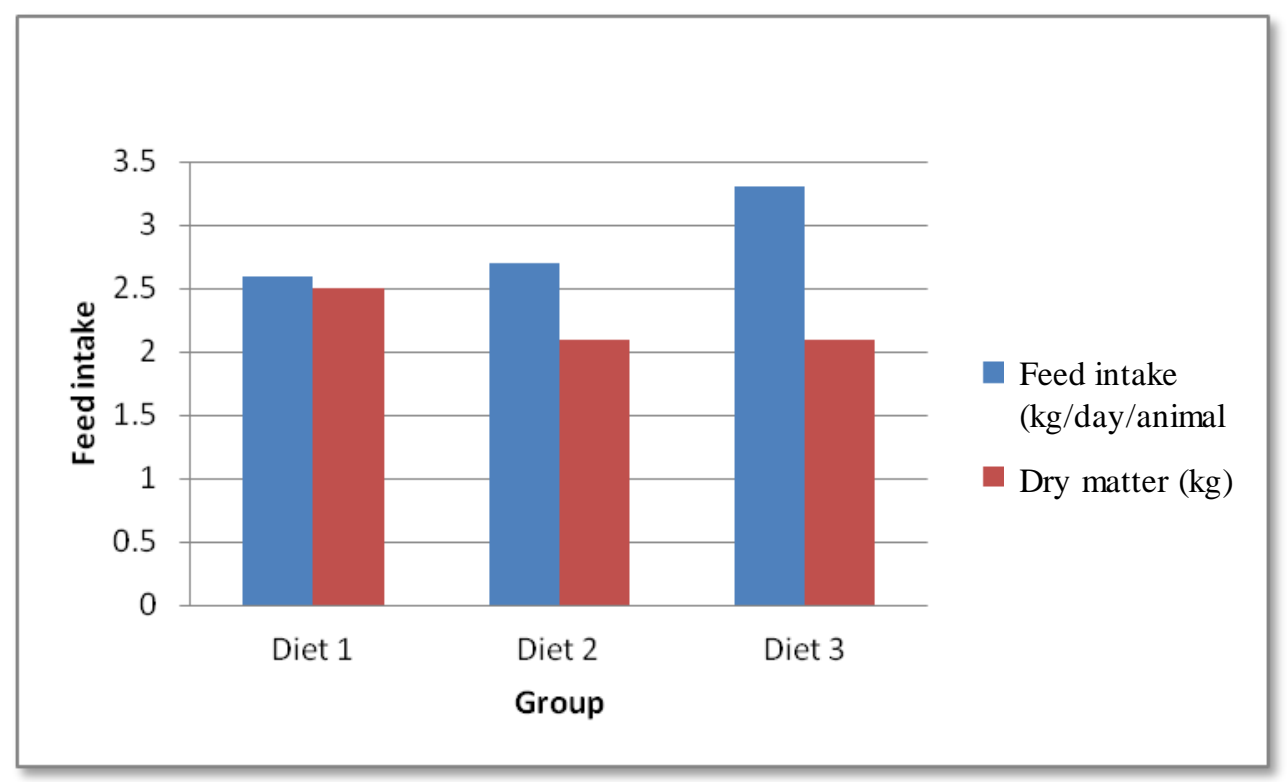

Figure 3. Feed intake for Diet 1, Diet 2 and Diet 3

\section{Blood parameters}

In order to determine hematological changes on stress parameter, leucocytes count, neutrophils and lymphocytes count were analyzed. Then, N:L ratio can be evaluated from neutrophils and lymphocytes count which widely used as stress indicator in livestock. The leucocytes count showed the highest on Diet 1, followed by Diet 3 and Diet 2. There was no significant difference $(\mathrm{P}>0.05)$ of leucocytes count for all groups as compared to normal limit of caprine leucocytes count (Figure 4). 


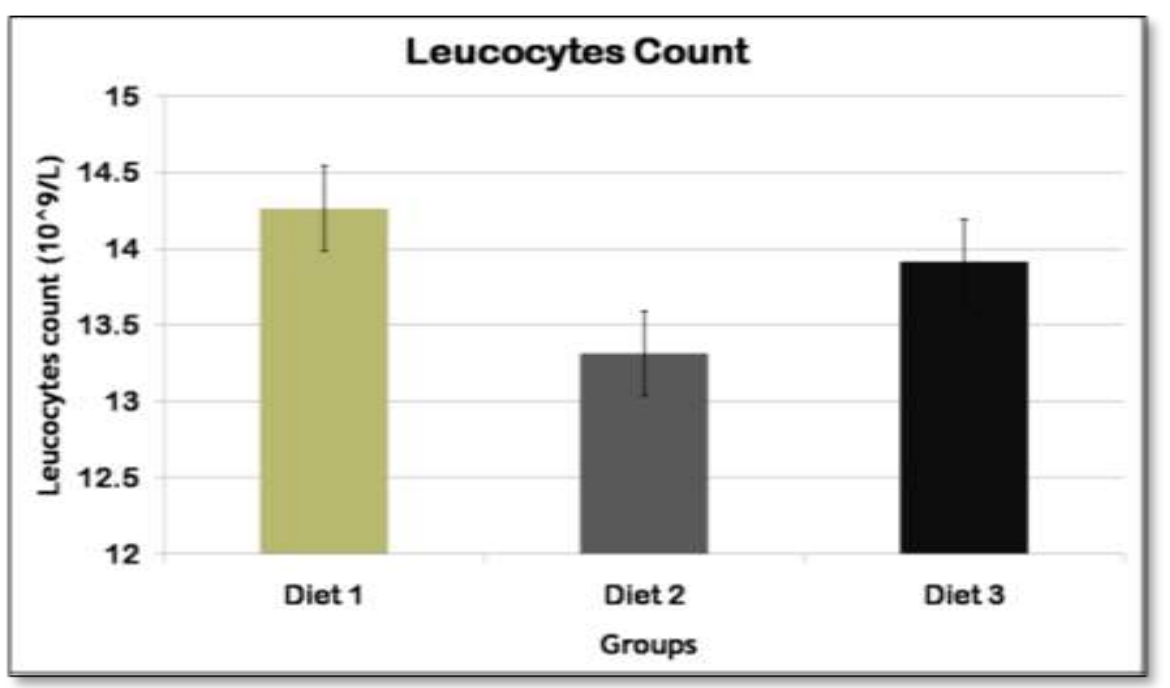

Figure 4. Leucocytes count for Diet 1, Diet 2 and Diet 3

The neutrophils and lymphocytes count for all groups were within normal range of caprine neutrophils and lymphocytes count (Figure 5).

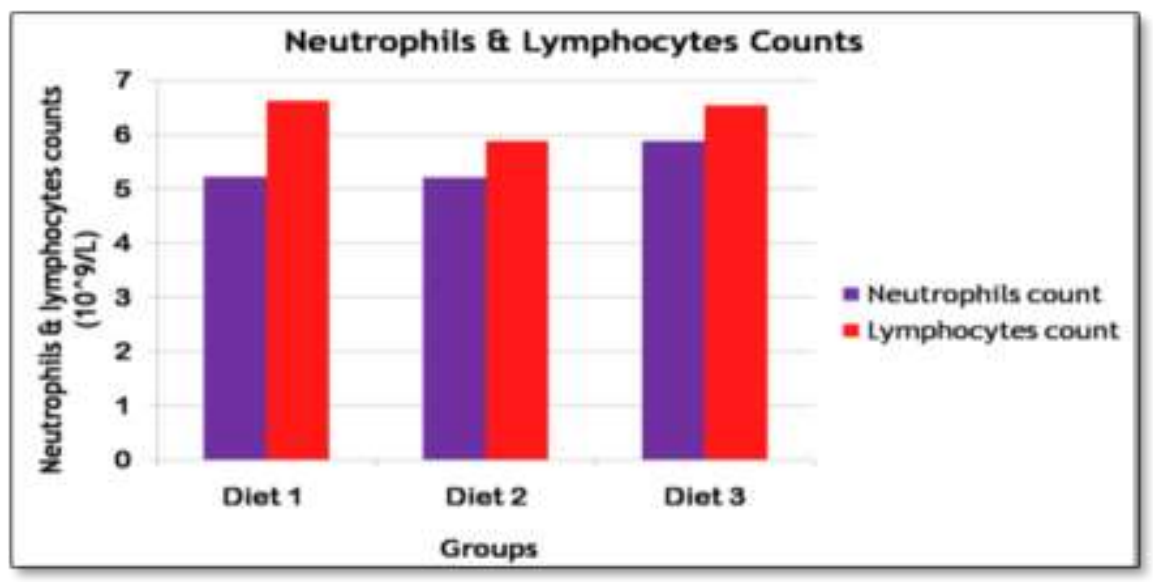

Figure 5. The neutrophils and lymphocytes counts for Diet 1, Diet 2 and Diet 3

Neutrophils:lymphocytes ratio for all groups were within normal range. There was no significant difference $(\mathrm{P}>0.05)$ for all groups on neutrophils:lymphocytes ratio (Figure 6).

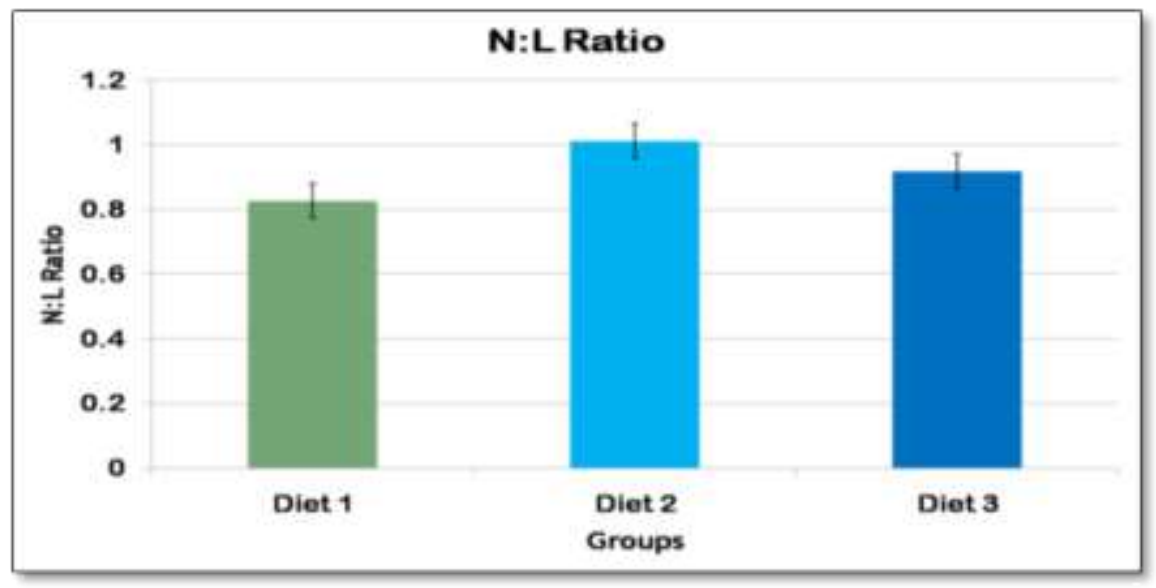

Figure 6. The neutrophils:lymphocytes ratio for Diet 1, Diet 2 and Diet 3 


\section{Discussion}

The performance of the goat will be increased when the feed provided meets the daily requirement. Higher quality of feed will show a better body weight gain as the feed consists of required nutrients by the goat which includes energy, crude protein, fiber, fat, and vitamins.Body weight gain and feed intake are among the indicators which frequently being evaluated in animal to asses their performance. Body weight gain of the goat is influenced by various factors namely genetic, nutrition, health status and management system (Christopher 2012). Genetically, Boer goat is having higher body weight gain as compared to local Katjang goat even when they are provided with feed with similar quality and quantity.Dietary energy content in the feed is the main dietary factor which controls voluntary feed intake. In ruminant, the blood concentration of volatile fatty acids is the principal regulator of feed intake. According to Cheeke \& Dierenfeld (2010), propionate concentration in the liver is a major satiety signal in ruminant. Oxidation of metabolic fuels in the liver will stimulate satiety centre in the hypothalamus which directly affectsfeed intake by the animal. It is also known as hepatic oxidation theory of the control of feed intake.

In this study, the diet 3 shows highest increase in body weight gain as well as average daily gain. This is because diet 3 formulation has highest soy waste and local plants (Mallotus sp. and Macaranga sp.) proportions which have high crude protein percentage as compared to Napier grass. Soy waste has high nutritive value and no negative effects on the feed intake and weight gain, thus, it is suitable to be used to replace commercial feed (Li et al. 2013). This result concurs with the research done by Rahman et al. (2015) and Feng (2007), where there is a higher average body weight gain in a group of goats given with soy waste which could attribute to higher crude protein of the soya waste as compared to that of the pelleted compound feed and Napier grass. There was no study has been done before to see the effects of using Mallotus sp. and Macaranga sp. as an alternative feed source to replace Napier grass. However, based from study done by Ghani et al. (2015) to analyze the nutritive value of the local plant, he found out that Mallotus sp. and Macaranga sp. have high dry matter and crude protein content when compared to Napier grass. This show that the local plant could be used as an alternative sourceof feeding to the goats.

Generally, the leucocytes count will be increased due to several factors namely infection or inflammation or animal in a stressful condition. During stress, various endocrine responses are involved to improve fitness of the affected individual. The firstline hormone that plays an important role in overcoming stress is glucocorticoids (Möstl \& Palme 2002). Stress causes reduction in circulating lymphocytes due to redistribution from circulatory system into other body compartments. In farm management, stress among goats can occur due to many factors, such as overcrowding and transition of different feed regime given to the animals. In this study, blood parameters were analyzed to see the effect of different feed formulation among the goats in the farm.

From the blood results, all does from Diet 1, Experimental Diet 2 and Diet 3 were all within the normal range and no increment in lymphocytes and neutrophils count. From neutrophils and lymphocytes counts, neutrophils:lymphocytes ratio also can be calculated. Neutrophils:lymphocytes ratio is the commonest stress indicator in livestock. It is influenced by many individual factors namely sex and age of the animal. The normal neutrophils:lymphocytes ratio for a mature doe is ranging from 0.6 to 3.6 (Mary \& David 2011) and the normal neutrophils:lymphocytes ratio for about one-year-old doe is ranging from 0.5 to 1.1 (Bradford 2014). In this study, all does from Control Diet 1, Experimental Diet 2 and Diet 3 were within the normal range, thus, it indicates there is no stressful 
condition. There is a study on neutrophils:lymphocytes ratio as the stress indicator in goats during transportation by Idrus et al. (2010), the elevation of neutrophils:lymphocytes ratio into 1.5 to 2.5 may indicate stress among goats. Therefore, no stress is being detected within does for all of the different feed formulation within four weeks of experimental period.

\section{CONCLUSION}

Different feed formulation would improve the performance of the goat specifically on body weight gain and feed intake. During four weeks of the experimental period, the implementation of different feed formulation would not cause significant stress to the animals. The high quality of feed from local resources with sufficient amount of its nutrient must be considered to ensure the goats are receiving enough daily requirements. Thus, feeding management is one of the keys towards the successful livestock production system.

\section{REFERENCES}

Abubakr A, Alimon AR, Yaakub H, Abdullah N, Ivan M. 2015. Effect of feeding palm oil byproducts based diets on muscle fatty acid composition in goats. PLoS One. 10:1-12.

Alam MM, Hashem MA, Rahman MM, Hossain MM, Haque MR, Sobhan Z, Islam MS. 2011. Effect of heat stress on behaviour, physiological and blood parameters of goat. J Chem Inf Model. 53:1689-1699.

Bradford PS. 2014. Normal values for leukogram data for adult animals. Large Animal Internal Medicine Fifth Edition, Elsevier. p. 382.

Cheeke PR, Dierenfeld ES. 2010. Comparative animal nutrition and metabolism. Wallingford (UK): CABI Publishing. $352 \mathrm{p}$.

Christopher DL. 2012. Boer goat production: progress and perspective. Hilo (USA): University of Hawai'i.

Devendra C. 2013. Investments on pro-poor development projects on goats: Ensuring success for improved livelihoods. Asian-Australasian J Anim Sci. 26:1-18.

Fazio E, Medica P, Cavaleri S, Cravana C, Ferlazzo A. 2006. Cortisol levels as indicator of stress in domestic goast under different housing systems [Internet]. Available from: http://www2.vet.unibo.it/staff/Gentile/Femesprum/Pdf. p. 147-150.

Feng J, Liu X, Xu ZR, Lu YP, Liu YY. 2007. The effect of Aspergillus oryzae fermented soybean meal on growth performance, digestibility of dietary components and activities of intestinal enzymes in weaned piglets. Anim Feed Sci Technol. 134:295-303.

Filley S, Peters A, 2006. Goat nutrition feeds \& feeding. Hood River County (USA): Oregon State University Extension Service.

Ghani AAA, Shahudin MS, Hassim H. 2015. Nutrient Composition and In Vitro Ruminal Degradability of Selected Local 1 Plants Used As Goat Feed in Malaysia. Proceeding The 5thInternational Conference on Sustainable Animal Agriculture for Developing Countries. Pattaya, 27-30 October. 2015. Pattaya (Thailand): Rajamangala University of Technology Isan. p. 81.

Harjanti DW, Sugawara Y, Al-Mamun M, Sano H. 2012. Effects of replacing concentrate with soybean curd residue silage on ruminal characteristics, plasma leucine and glucose turnover rates in sheep. J Anim Sci Adv. 2:361-374. 
Idrus Z., Bahyuddin N., Cheah YW, Soleimani AF, Sazili AQ, Rajion MA, Goh YM. 2010. Physiological responses in goats subjected to road transportation under the hot, humid tropical conditions. Int J Agric Biol. 12:840-844.

Li S, Zhu D, Li K, Yang Y, Lei Z, Zhang Z. 2013. Soybean curd residue: composition, utilization, and related limiting factors. ISRN Industrial Engineering, 2013.

Mary CS, David MS. 2011. Leucocytes parameter. Goat Medicine 2nd edition. Wiley-Blackwell Publishing.

Möstl E, Palme R. 2002. Hormones as indicators of stress. Dom Anim Endocrinol. 23:67-74.

Mustafa MY, Shahid M, Mehmood B. 2010. Management practices and health care of buffalo calves in Sheikhupura District, Pakistan. Buffalo Bull. 29:217-224.

Rahman MM, Nakagawa T, Abdullah RB, Embong WKW, Akashi R. 2014. Feed intake and growth performance of goats supplemented with soy waste. Pesqui Agropecu Bras. 49:554558.

Ramsey LL. 2012. Effects of including okara into the diet of post-weanling crossbred Boer goats and its impact on growth and performance. [Thesis]. [Commerce (USA)]: Texas A\&M University-Commerce.

Rahman MM, Rahman MR, Nakagawa T, Abdullah RB, Khadijah WEW, Akashi R. 2015. Effects of wet soya waste supplementation on the intake, growth and reproduction of goats fed Napier grass. Anim Feed Sci Technol. 199:104-112. [Internet]. Available from: http://dx.doi.org/10.1016/j.anifeedsci.2014.11.007

Sultana S, Khan MJ, Hassan MR, Khondoker MAMY. 2012. Effects of concentrate supplementation on growth, reproduction and milk yield of Black Bengal goats (Capra hircus). The Bangladesh Vet. 29:7-16. 